Alaska Division of Geological \& Geophysical Surveys

RAW-DATA FILE 2017-8J

\title{
PHOTOGRAMMETRIC DIGITAL SURFACE MODELS AND ORTHOIMAGERY FOR THE CONTINUOUS COASTLINE, WALES TO PLATINUM, ALASKA
}

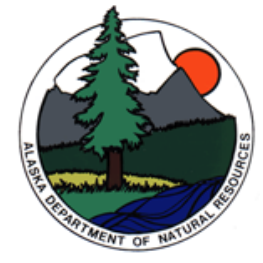

\author{
SEGMENT J: NEWTOK TO TOKSOOK BAY \\ by \\ Jacquelyn R. Overbeck ${ }^{1}$, Michael D. Hendricks ${ }^{1}$, and Nicole E.M. Kinsman²
}

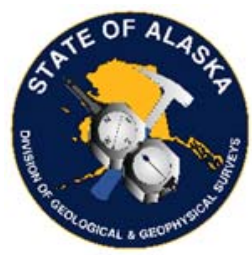

December 2018

\section{Summary}

These data are one segment of a set of data collected continuously along the western coast of Alaska (fig. 1). Data are in their raw format of orthoimage raster and Digital Surface Model (DSM) raster processed to $20 \mathrm{~cm}$ Ground Sample Distance (GSD), without using vertical control; community-level data where vertical controls have been rigorously applied, are higher resolution, and have fewer gaps, see Overbeck and others (2016;

http://dggs.alaska.gov/pubs/id/29548). General data collection, processing, and accuracy assessment procedures in this release are described in a data release overview (Overbeck and others, 2017; http://doi.org/10.14509/29744). Checkpoints used for quality control will be published for public access at a later date.

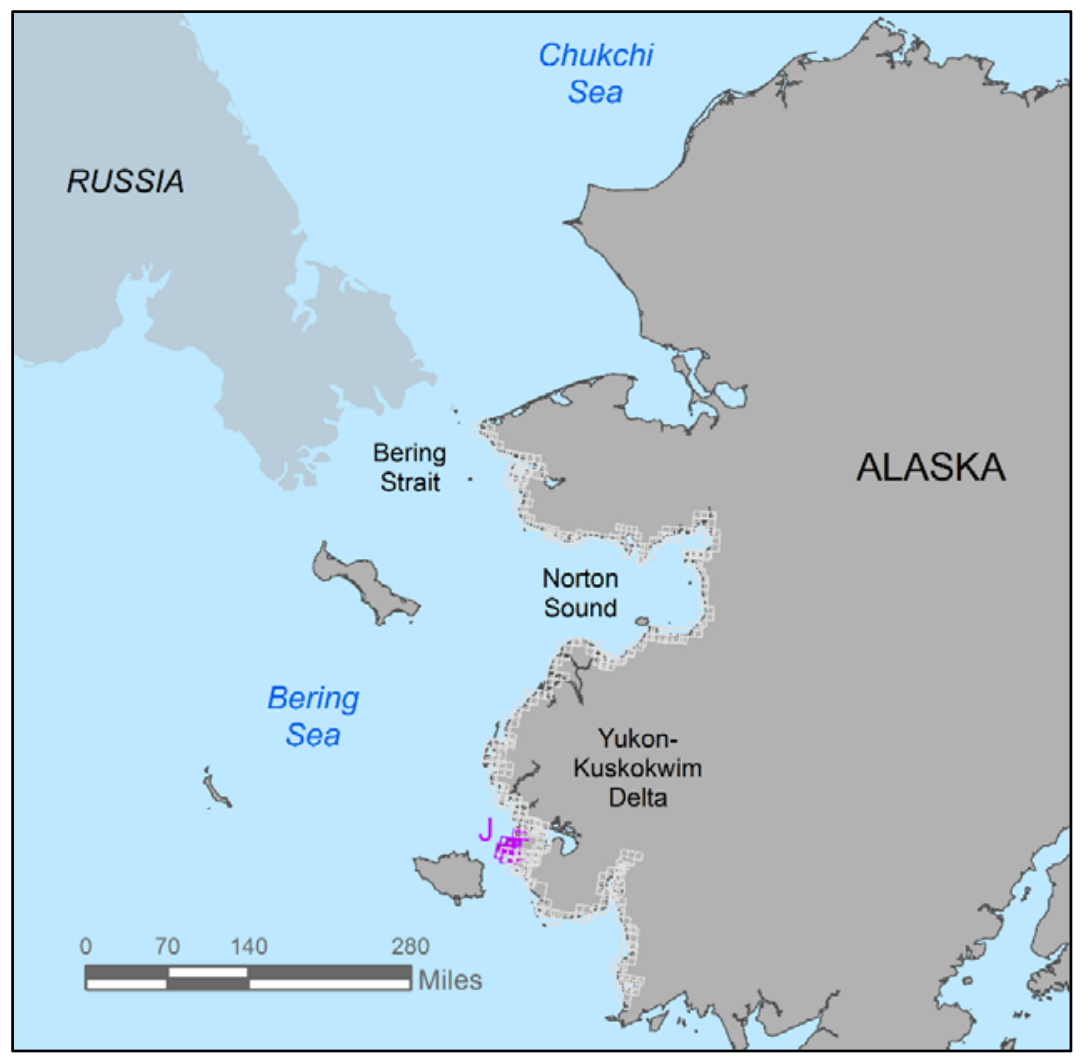

Figure 1. Map showing extent of orthorectified areal imagery and elevation data for the continuous coastline (light gray) segment from Newtok to Toksook Bay (purple; collected by Fairbanks Fodar, 2015-2016).

\footnotetext{
${ }^{1}$ Alaska Division of Geological \& Geophysical Surveys, 3354 College Road, Fairbanks, AK, 99709-3707; jacquelyn.overbeck@alaska.gov

${ }^{2}$ Alaska Division of Geological \& Geophysical Surveys, 3354 College Road, Fairbanks, AK, 99709-3707; now at NOAA/NOS/National Geodetic Survey (NGS), 222 West $7^{\text {th }}$ Avenue, Room 517, Anchorage, AK 99513-7575
} 


\section{Data Organization}

Data for this region and the checkpoints used for quality control are projected to NAD83 UTM Zone 3N relative to NAVD88 Geoid 12A, EPOCH 2010.00.

\section{Data Quality}

Since no ground control points were used to vertically or horizontally control these data, all ground control and checkpoints points are considered checkpoints for this accuracy assessment. Data quality have been assessed relative to checkpoints collected simultaneously with the aerial survey described in the community scale data release (Overbeck and others, 2016). Although these checkpoints are focused at community locations and at large alongshore intervals, they have been used to assess the accuracy of these data at a regional scale. Photo-identifiable points were used to determine the horizontal accuracy of these data (table 1), while all points were used to determine the vertical accuracy unless the ground cover was irregular and non-vegetated (e.g. boulder piles) (table 2). Data within this alongshore segment may overlap with data in an adjacent segment, and data segments may not overlap seamlessly.

Table 1. Horizontal accuracy statistics calculated comparing checkpoints to orthoimagery using standards from the American Society of Photogrammetry and Remote Sensing (2015).

\begin{tabular}{|l|c|}
\cline { 2 - 2 } \multicolumn{1}{c|}{} & Checkpoints \\
\hline RMSE $_{r}$ & $0.236 \mathrm{~m}$ \\
\hline $\begin{array}{l}\text { positional accuracy at } \\
\text { 95\% confidence }\end{array}$ & $0.462 \mathrm{~m}$ \\
\hline number of points used & 3 \\
\hline
\end{tabular}

Table 2. Vertical accuracy statistics calculated comparing checkpoints to DSM using standards from the American Society of Photogrammetry and Remote Sensing (2015).

\begin{tabular}{|l|c|c|}
\cline { 2 - 3 } \multicolumn{1}{c|}{} & $\begin{array}{c}\text { Non-vegetated } \\
\text { Checkpoints }\end{array}$ & $\begin{array}{c}\text { Vegetated } \\
\text { Checkpoints }\end{array}$ \\
\hline$R M S E z$ & $0.209 \mathrm{~m}$ & $0.207 \mathrm{~m}$ \\
\hline $\begin{array}{l}\text { vertical accuracy at } \\
\text { 95\% confidence level }\end{array}$ & $0.409 \mathrm{~m}$ & $0.405 \mathrm{~m}$ \\
\hline mean residual & $0.166 \mathrm{~m}$ & $0.187 \mathrm{~m}$ \\
\hline number of points used & 9 & 4 \\
\hline
\end{tabular}

\section{Acknowledgments}

This publication is funded with qualified outer continental shelf oil and gas revenues by the Coastal Impact Assistance Program, U.S. Fish and Wildlife Service, U.S. Department of the Interior. The views and conclusions contained in this document are those of the authors and should not be interpreted as representing the opinions or policies of the U.S. Government. Mention of trade names or commercial products does not constitute their endorsement by the U.S. Government.

\section{References}

American Society for Photogrammetry and Remote Sensing (ASPRS), 2015, ASPRS Positional Accuracy Standards for Digital Geospatial Data: Photogrammetric Engineering \& Remote Sensing, v. 81, no. 3, p. A1-A26. http://doi.org/10.14358/PERS.81.3.A1-A26 
Overbeck, J.R., Hendricks, M.D., and Kinsman, N.E.M., 2016, Photogrammetric digital surface models and orthoimagery for 26 coastal communities of western Alaska, in DGGS Staff, Elevation Datasets of Alaska: Alaska Division of Geological \& Geophysical Surveys Raw Data File 2016-1, 3 p. http://doi.org/10.14509/29548

Overbeck, J.R., Hendricks, M.D., and Kinsman, N.E.M., 2017, Photogrammetric digital surface models and orthoimagery for the continuous coastline, Wales to Platinum, Alaska: Alaska Division of Geological \& Geophysical Surveys Raw Data File 2017-8, 7 p. http://doi.org/10.14059/29744 